Annals of Tropical Research 30[1]:15-28 (2008)

(c) VSU, Leyte, Philippines

\title{
Incidence of sweetpotato viruses in Central Luzon, Philippines
}

\author{
Erlinda A. Vasquez ${ }^{1}$, Manuel K. Palomar ${ }^{2}$, Lilibeth B. Laranang ${ }^{3}$ and \\ Edgardo B. Barsalote ${ }^{1}$ \\ ${ }^{I}$ PhilRootcrops, Visayas State University, Baybay, Leyte, 6521-A, Philippines; \\ ${ }^{2}$ Department of Pest Management, Visayas State University, Baybay City, Leyte, \\ Philippines; ${ }^{3}$ Tarlac State University, Camiling, Tarlac, Philippines
}

\begin{abstract}
Sweetpotao commercial growing areas in Central Luzon particularly Tarlac and Bataan were surveyed for the incidence of sweetpotato viruses. Healthy-looking sweetpotato leaves and those showing symptoms of virus infection were collected and subjected to nitrocellulose membrane-enzyme linked immunoabsorbent serological assay (NCM-ELISA) for the detection of known viruses using the kit and protocol from Centro Internacional de la Papa, Lima Peru. The NCM-ELISA detected sweetpotato feathery mottle virus (SPFMV), sweetpotato mild mottle virus (SPMMV), sweetpotato latent virus (SPLV), sweetpotao chlorotic fleck virus (SPCFV), C-6 virus, sweetpotato mild speckling virus (SPMSV), sweetpotato caulimo-like virus (SPCalV), and sweetpotato chlorotic stunt virus (SPCSV). Six to 8 viruses were found in Tarlac and 3-4 viruses in Bataan. Highest infections were recorded for C-6, SPMSV, SPCalV and SPCSV reaching $100 \%$ in almost all areas. Infection of SPFMV ranged from $45-70 \%$. The combination of SPFMV with other viruses was common registering 40-70\% complex infection. Mixed infection of 3-6 viruses (SPFMV, SPMMV, SPLV, C-6, SPMSV and SPCalV) was found in Tarlac and 2-4 viruses (SPFMV, C-6, SPMSV and SPCalV) in Bataan. Practically all sweetpotato growing areas of Tarlac are "hotspot" areas of sweetpotato viruses.
\end{abstract}

Keywords: sweetpotato virus diseases, identification, incidence, SPFMV, SPMMV,SPLV, SPCFV, C-6, SPMSV, SPCalV, SPCSV, serological test, NCM-ELISA, Central Luzon

Correspondence: E. A. Vasquez Address: PhilRootcrops, Visayas State University, Baybay City, Leyte, 6521-A, Philippines. E-mail: lindvasq@yahoo.com Tel. No. (053) 335-2616; Fax No. (053) 335-2601

DOI: $10.32945 /$ atr3012.2008 


\section{INTRODUCTION}

Sweetpotato is grown throughout the Philippines but commercial farms are concentrated in Central and Western Luzon where it is grown after rice. Virus diseases can pose a significant constraint to sweetpotato production; sweetpotato virus diseases ravaged more than 10,000 hectares of sweetpotato grown after rice in Central Luzon in 1998. This has caused significant reduction in yield resulting in lost income to many growers. Some have failed to attain break-even income from what used to be a quick lucrative income derived during the months when rice cannot be grown due to lack of irrigation.

In Central Luzon, the virus diseases wiped out the most popular variety called "Bureau" during the disease outbreak in 1989 and 1990. This was replaced by VSP 6 locally known as "Super Bureau" (Amante and Rasco, 1995). Although of relatively inferior root qualities as compared to Bureau, VSP 6 has gained acceptance because of its high yield, early maturity and red skin, a characteristic preferred by traders and consumers. At present about $90 \%$ of all the sweetpotato planted in Tarlac and Bataan is VSP6 while the remaining $10 \%$ consist of other varieties like Bentong, Ubi, Taiwan and Binicol. While VSP6 has shown tolerance to virus diseases for quite sometime, it has now succumbed to virus diseases.

The current major problem in sweetpotato production in Central Luzon is the incidence of a disease locally known as "camote-kulot". Yield losses of more than $50 \%$ have been reported due to the use of infected planting materials (Jayasinghe and Laranang, 1999).

The disease that wiped out variety Bureau and presently affecting Super Bureau (VSP 6) is identified as sweetpotato feathery mottle virus (SPFMV) based on symptoms. However, closer examination of the symptoms expressed in infected plants suggests the possibility of other viruses simultaneously infecting sweetpotato. Sweetpotato virus disease (SPVD) is the name that has become associated with a serious disease of sweetpotato, symptoms of which typically includes leaf distortion, chlorosis, discoloration, and stunting. These symptoms are also typical for sweetpotato infected with "camote kulot" disease. Works in West and East Africa showed that it is caused by combined infection with aphid-borne SPFMV and whitefly-borne sweetpotato chlorotic stunt virus (SPCSV) (Schaefers and Terry, 1976; Winter et al., 1992; Hoyer et al., 1996; Gibson et al., 1998). 
Recent studies on the occurrence of sweetpotato viruses in a number of countries are helping to clarify our understanding of the global importance of sweetpotato viruses and to define control strategies (Carey et al. 1999). There are already 20 recognied viruses known to infect sweetpotato all over the world, 8 of which are found in the Philippines (Salazar and Fuentes, 2000). Jayasinghe and Laranang (1999) reported 7 viruses present in Tarlac.

Sweetpotato feathery mottle virus (SPFMV) disease alone does not usually cause severe yield reduction in sweetpotato, but mixed infections of SPFMV with other viruses are the main cause of crop degeneration (CIP, 1995. SPFMV is deceiving because virus-infected plants (or roots) are not destroyed, as in the case with most other diseases. The combination of viruses in sweetpotato commonly referred as sweetpotato viruses disease or SPVD is considered the major cause of sweetpotato decline in other countries (Carey et al., 1999; Gibson et al., 1998). Gutierez et al. (1999) reported synergistic effect of SPFMV and SPCSV causing yield loss of more than $50 \%$ in two sweetpotato varieties.

In the Philippines, SPFMV caused 11-64\% yield reduction of sweetpotato in Leyte (Palomar et al., 2000) while losses of 84.5-98.1\% in tuberous roots due to SPFMV in association with "camote kulot" disease was reported in Luzon (Villegas, et al. 1996). In sweetpotato, many virus diseases are a result of synergistic action among viruses, notably between SPFMV and other agents, and SPFMV is frequently isolated from naturally infected sweetpotato, obscuring detection of associated viruses.

The sweetpotato viruses such as SPFMV, SPLV, SPMSV are vectored by aphids (Aphis gossypii and Myzus persicae) while SPMMV and SPCSV by whiteflies (Bemesia tabaci) (Chung, 1986; Salazar and Fuentes, 2000). Insect transmission of other viruses is still unknown.

This study was conducted to identify the different viruses infecting sweetpotato, their incidence and "hot spot" areas of virus infection in commercial sweetpotato growing areas in Central Luzon particularly the provinces of Tarlac and Bataan. 


\section{MATERIALS AND METHODS}

\section{Survey and collection of diseased sweetpotato}

Healthy looking and virus-infected sweetpotato samples were collected in commercial sweetpotato growing areas of Tarlac and Bataan to cover 4 municipalities of the former and two municipalities in the latter with two barangays per municipality. Shoots of plants showing visible symptoms were collected. Samples were taken from representative infected plants in the marked $\mathrm{X}$ or $\mathrm{Z}$ sampling portions of the field. The collected plants were placed individually in plastic polyethylene bag and placed in a cool box.

\section{Identification of sweetpotato viruses through serological test using NCM-ELISA}

Detection and identification of sweetpotato viruses was done using Nitrocellulose Membrane-Enzyme Linked Immunosorbent Assay (NCMELISA) following the protocol established by the Centro Internacional de la Papa (CIP). NCM-ELISA is an immunoenzymatic test that uses nitrocellulose membrane instead of the polysterne microtitration plates as support for the reagents used in the serological reaction. This test is as sensitive as the direct double sandwich ELISA (DAS-ELISA), simpler to perform and can be completed in a shorter period of time. It has also another very important advantage: the sample can be spotted on the membrane and stored for several weeks before continuing with the test, or it can be sent to another laboratory for development. The NCM-ELISA kit from CIP, Lima, Peru containing 8 antisera of the 8 sweetpotato (SP) viruses was used in all the tests.

\section{Preparation of sample}

A composite sampling from every collected plant to be tested was done by taking one leaf each from the top, middle and bottom levels showing symptoms. From each leaf sample, a disk approximately $1 \mathrm{~cm}$ in diameter was cut using a small test tube by exerting pressure on the outside of the plastic bag. The remaining part of the leaf was discarded and the leaf disk was ground with $3 \mathrm{ml}$ extraction buffer of $0.2 \%$ sodium sulfite using the bottom of 
the test tube. The bag filled with macerated tissue in extraction buffer was allowed to stand for 30-45 minutes inside the refrigerator prior to spotting onto NCM.

\section{Spotting of samples to nitrocellulose membrane}

A dry plastic cling wrap was placed on the laboratory bench. Adry sheet of filter paper with the NCM on top was placed on the cling wrap. With the use of a clean pipette, one drop (about $17 \mu \mathrm{l}$ ) of the supernatant from the macerated tissue in extraction buffer was spotted onto the NCM (Fig. 1). The membrane was allowed to dry. The dried NCM was placed between 2 dry filter papers and protected with cardboard for storing until ready for processing.

\section{Development of the spotted-NCM}

The spotted-NCM was immersed in $30 \mathrm{ml}$ of blocking buffer of $2 \%$ powdered cow's milk in Tris-buffer solution (TBS) $\mathrm{pH} 7$ together with the positive control NCM strip and incubated for 60 minutes. The blocking solution was discarded and washed rapidly with TBS (pH 7.5). Then, $30 \mathrm{ml}$ of the antibody buffer for each virus was added separately onto each plate and sealed with parafilm and incubated overnight. The primary antibody solution was discarded and the unbound antibodies were removed by washing the membrane with constant agitation in $30 \mathrm{ml} \mathrm{TBS}+2 \%$ Triton-X 100 blocking solution four times for 3 minutes each. The blocking solution was discarded and the membranes were placed in between blotting papers to remove excess solution. The membranes were placed back in the petri dish and $30 \mathrm{ml}$ conjugate buffer of $2 \%$ powdered cow's milk was added and incubated for 1 hour. The conjugate solution was discarded and the unbound secondary antibodies of the conjugate were removed by washing with T-TBS (TBS containing $0.2 \%$ Tween 20) four times for 3 minutes each. The membranes were removed and placed in between blotting paper to remove excess solution. The membranes were placed back in the petri dish and $25 \mathrm{ml}$ of the colour development solution of nitro blue tetrazolium/5-bromo-4-chloro-3-indolyl phosphate in dimethyl formamide (NBT/BCIP in DMF) was added. The reaction was allowed to take place for 30 minutes. Positive reactions were those showing different grades of purple color. The color development was stopped by discarding the 


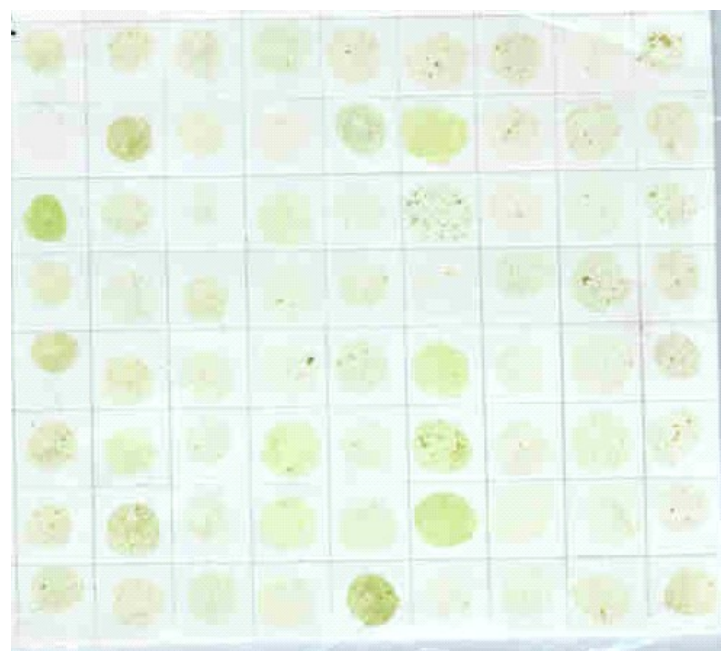

Fig. 1. Nitrocellulose membrane spotted with sweetpotato virus extract

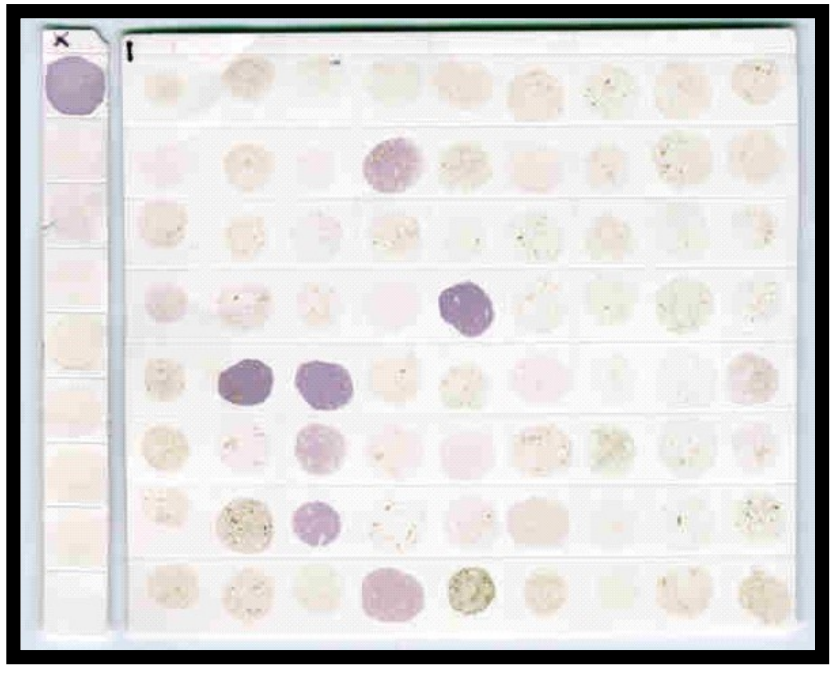

Fig. 2. Developed-NCM spotted with virus extract showing positive reaction to SPFMV. (A) Control lane showing positive reaction to SPFMV as purple spots (B) Reaction of different samples to SPFMV 
color development solution and immersing the membrane in distilled water. The NCMs were washed in distilled water for 10 minutes, changing the water at least three times during that period. The NCMs were dried on filter paper and stored between dry filter papers.

\section{RESULTS AND DISCUSSION}

\section{Field survey}

The areas covered in the survey were two barangays in each of the four municipalities of Tarlac; namely, Gerona, Panique, Moncada and Capas, and two municipalities of Bataan, Bagac and Balanga, where sweetpotato was grown in commercial scale.

Virus infection in farmers' fields planted with VSP 6 ranged from 5-60\% (Table 1). Except in Camp O'Donnell, all areas planted to sweetpotato in Tarlac were heavily infected with SPFMV and other viruses. Incidence of virus infection ranged from $40-60 \%$. Infection was relatively low in Bataan with disease incidence ranging from 6 to $25 \%$.

\section{Symptoms of virus-infected sweetpotato}

The virus-infected sweetpotato plant showed one or more of following symptoms: feathery mottle, vein clearing and yellowing of main veins, mosaic pattern in leaves, purple to brown rings and/or line patterns in older leaves, yellow spots, anthocyanescence, curling, crinkling, malformation and reduction in size of some leaves, rugousity in severely infected leaves, short internode, general stunting or dwarfing (Fig. 3). Severely infected plants formed bushy appearance without any vines and produced either only small storage roots or none at all.

\section{Identification of sweetpotato viruses}

The serological tests using NCM-ELISA in infected sweetpotato revealed simultaneous infection of 2 or more viruses in a plant producing a disease called "camote kulot". The NCM-ELISA kit detected 8 viruses (Table 2). 
Table 1. Area planted to sweetpotato variety VSP 6 and incidence (\%) of virus diseases based on visible symptoms in different sampling sites in Tarlac and Bataan in May and June, 2002

\begin{tabular}{lllcc}
\hline Province & Municipality & Barangay & $\begin{array}{c}\text { Area Planted } \\
(\mathrm{m} 2)\end{array}$ & \% Virus Infection \\
\hline \multirow{2}{*}{ Tarlac } & Gerona & Tagumbao & 640,000 & 54 \\
& & Danzo & 10,000 & 40 \\
& Panique & Rang-ayan & 33,000 & 51 \\
& & Camangan & 10,000 & 60 \\
& Moncada & Sapang & 36,000 & 43 \\
& & Baloang West & 15,300 & 23 \\
& Capas & Sta. Juliana & 5,000 & 42 \\
\multirow{5}{*}{ Bataan } & Camp O’Donell & 7,000 & 38 \\
& \multirow{2}{*}{ Balanga } & Cupang & 5,000 & 6 \\
& & Dangcol & 2,500 & 25 \\
& Bagac & San Antonio & 10,000 & 20 \\
& & Parang & 7,500 & 5 \\
\hline
\end{tabular}

These include the sweetpotato feathery mottle virus (SPFMV), sweetpotato mild mottle virus (SPMMV), sweetpotato latent virus (SPLV), sweetpotato chlorotic fleck virus (SPCFV), C-6 virus, sweetpotato mild speckling virus (SPMSV), sweetpotato caulimo-like virus (SPCal-V), and sweetpotato chlorotic stunt virus (SPCSV). SPFMV, SPLV, SPMSV, SPCFV and C-6 belong to potyvirus group while SPMMV, SPCSV and SPCalV are characterized as epimovirus, crinivirus and caulimo-virus, respectively (Salazar and Fuentes, 2000).

Occurrence of sweetpotato viruses was highest in Paniqui, Tarlac (8), followed by Gerona and Capas, Tarlac (7), Moncada (6), Bagac, Bataan (4) and Balanga, Bataan (3) (Table 3). Although SPFMV is known to be widely distributed, it was not detected in Balanga, Bataan. Infection of SPFMV, however was not as high as those of the other 3 viruses ranging only from 45 to $70 \%$. Combination of SPFMV with other viruses such as SPMMV, C-6, SPMSV, SPCalV and SPCSV was commonly observed. If SPFMV was not present, combination of C-6, SPMSV, SPCalV and SPCSV was often detected. Amixed infection of 3-6 viruses was prevalent in Tarlac while 2-4 viruses in Bataan (Table 4). 
Incidence of sweetpotato viruses

Table 2. Viruses in sweetpotato in Bataan and Tarlac, Central Luzon, Philippines

\begin{tabular}{|c|c|c|c|c|c|c|c|c|}
\hline Location & FMV & MMV & LV & CFV & C-6 & MSV & CalV & CSV \\
\hline \multicolumn{9}{|l|}{ Tarlac } \\
\hline \multicolumn{9}{|l|}{ Gerona } \\
\hline Danzo & + & - & - & + & + & + & + & + \\
\hline Tagumbao & + & + & - & - & + & + & + & + \\
\hline \multicolumn{9}{|l|}{ Paniqui } \\
\hline Camangnan & + & + & + & + & + & + & + & + \\
\hline Rang-ayan & + & + & + & + & + & + & + & + \\
\hline \multicolumn{9}{|l|}{ Moncada } \\
\hline Sapang & + & + & - & - & + & + & + & + \\
\hline Baloang West & + & + & - & - & + & + & + & + \\
\hline \multicolumn{9}{|l|}{ Capas } \\
\hline Sta. Juliana & + & + & + & - & + & + & + & + \\
\hline Camp O’Donnel & + & + & - & - & + & + & + & - \\
\hline \multicolumn{9}{|l|}{ Bataan } \\
\hline \multicolumn{9}{|l|}{ Balanga } \\
\hline Cupang & - & - & - & - & + & - & + & - \\
\hline Dangcol & - & - & - & - & + & + & + & - \\
\hline \multicolumn{9}{|l|}{ Bagac } \\
\hline San Antonio & + & - & - & - & + & + & + & - \\
\hline Parang & + & - & - & - & + & + & + & - \\
\hline
\end{tabular}

+ positve; - not detected

Table 3. Frequency of virus infection (\%) of sweetpotato leaf samples collected in commercial sweetpotato growing areas in Tarlac and Bataan detected by NCM-ELISA

\begin{tabular}{lrrrrrr}
\hline \multirow{2}{*}{ SP Viruses } & \multicolumn{6}{c}{ Tarlac } \\
\cline { 2 - 7 } & Gerona & Paniqui & Moncada & Capas & Balanga & Bagac \\
\hline SPFMV & 48.64 & 66.66 & 69.23 & 45.25 & 0 & 70.00 \\
SPMMV & 2.70 & 85.42 & 61.65 & 36.36 & 0 & 0 \\
SPLV & 0 & 14.27 & 0 & 0 & 0 & 0 \\
SPCFV & 8.10 & 9.52 & 0 & 9.09 & 0 & 0 \\
C-6 & 94.27 & 100.00 & 100.00 & 81.81 & 77.77 & 90.00 \\
SPMSV & 83.77 & 100.00 & 100.00 & 63.63 & 44.44 & 70.00 \\
SPCalV & 88.87 & 100.00 & 100.00 & 100.00 & 77.77 & 100.00 \\
SPCSV & 26.71 & 85.71 & 100.00 & 72.72 & 0 & 0 \\
\hline
\end{tabular}

Data based on samples collected and assayed serologically 
Table 4. Frequency (\%) of mixed infections of different virus diseases of sweetpotato leaf samples collected in Tarlac and Bataan

\begin{tabular}{lrrrrrr}
\hline \multicolumn{1}{c}{$\begin{array}{c}\text { Virus } \\
\text { Combination* }\end{array}$} & Gerona & Paniqui & Moncada & Capas & Balanga & Bagac \\
\hline $1-2-3-4-5-6-7-8$ & & 9.52 & 46.15 & & & \\
$1-2-5-6-7-8$ & 2.70 & 38.10 & & 9.09 & & \\
$1-2-7-8$ & & & & 9.09 & & \\
$1-2-7$ & & & & 9.09 & & \\
$1-4-5-6-7-8$ & 2.70 & & & & & \\
$1-5-6-7-8$ & 8.11 & 9.52 & 23.08 & 18.18 & & \\
$1-5-6-7$ & 32.43 & 9.52 & & & & \\
$1-5-6$ & 2.70 & & & & & \\
$1-6-7$ & & & & & & \\
$2-3-5-6-7-8$ & & 4.76 & & & & \\
$2-4-5-6-7-8$ & & 9.52 & & & & \\
$2-5-6-7-8$ & & 4.76 & & & & \\
$2-6-7$ & & & 4.76 & & & \\
$2-6-7$ & & & & 4.76 & & \\
$4-5-6-7-8$ & 5.40 & & & 9.09 & & \\
$5-6$ & & 4.76 & & 9.00 & \\
$5-6-7$ & 27.03 & 9.52 & 15.38 & 27.27 & 22.22 & \\
$5-6-7-8$ & 2.70 & & & 9.09 & & \\
$5-7-8$ & & & & & & \\
$5-7$ & 5.40 & & & & & \\
5 & 5.40 & & & & & \\
$6-7$ & & & & & & \\
7 & 2.70 & & & & & \\
8 & & & & & & \\
\hline
\end{tabular}

*1-SPFMV, 2-SPMMV, 3-SPLV, 4-SPCFV, 5-C-6, 6-SPMSV, 7-SPCalV, 8-SPCSV 

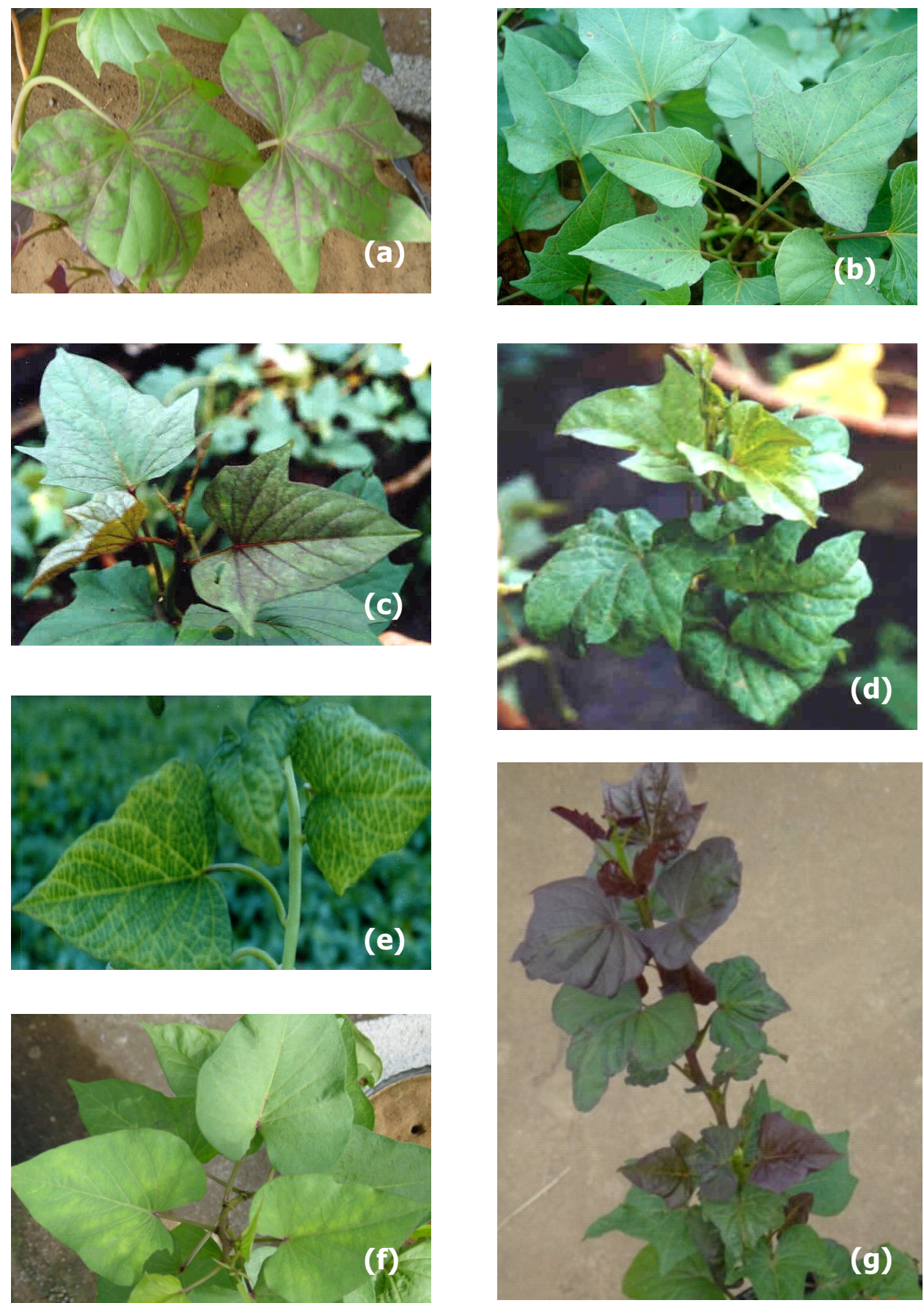

Fig. 3. Typical symptoms of virus-infected sweetpotato. (a) feathery mottle, (b) purple spots, (c) anthocyanescence, (d) vein yellowing, (e) vein clearing, (f) mottling and ( $g$ ) shortening of internodes (c to $g$ are symptoms of mixed infections) 
With these results, identification of individual virus based on symptoms alone therefore could not be done. Symptoms expressed in diseased plants overlapped with the typical symptoms manifested by individual viruses. With the number of viruses involved in mixed infections, correlation of symptoms with the viruses involved was difficult. Even healthy-looking plants were not free of virus diseases. Some were infected with C-6 viruses and SPCFV.

The results of the serological tests indicate that the current "camote kulot" disease is a complex and caused by simultaneous infections of 2 or more viruses.

\section{SUMMARY AND CONCLUSION}

Results of the survey based on visible symptoms indicated higher incidence of virus diseases in Tarlac (40-60\%) than in Bataan (6-25\%). Serological tests using NCM-ELISA in infected sweetpotato revealed the presence of 8 viruses, namely; sweetpotato feathery mottle virus (SPFMV), sweetpotato mild mottle virus (SPMMV), sweetpotato latent virus (SPLV), sweetpotato chlorotic fleck virus (SPCFV), C-6 virus, sweetpoto mild speckling virus (SPMSV), sweetpotato caulimo-like virus (SPCalV) and sweetpotato chlorotic stunt virus (SPCSV). All 8 viruses were found in Paniqui, Tarlac; all but SPLV in Gerona and Capas, Tarlac; and all except SPLV and SPCSV in Moncada, Tarlac. C-6, SPMSV and SPCalV were common in Balanga and Bagac, Bataan.

The current problem of "camote kulot" disease of sweetpotato in Central Luzon is due to virus complex with 2 or more viruses infecting the sweetpotato simultaneously. Combination of SPFMV with other viruses such as SPMMV, C-6, SPMSV, SPCalV and SPCSV was commonly observed. Mixed infection of C-6, SPMSV, SPCalV and SPCSV was also of high frequency.

\section{IMPLICATIONS AND RECOMMENDATION}

With the high pressure of virus infection in Tarlac, even healthy-looking plants are not safe to be considered healthy as some of the viruses present in 
the area produce no visible symptoms. Getting planting materials from farmers' field from Tarlac is unsafe and can contribute to the spread of the disease. Bataan which is not yet heavily infected with the viruses can be considered as site for multiplication of clean planting materials from virus-free mother plant and be the supplier of clean planting materials of Central Luzon.

\section{ACKNOWLEDGMENT}

The authors wish to thank the Department of Agriculture - Bureau of Agricultural Research (DA-BAR) for supporting the project on Interdiciplinary Management of Sweetpotato Feathery Mottle Virus in Central Luzon; the Department of Agriculture -Region III; the municipal agriculturists and technicians of DA-LGUs in Gerona, Moncada, Paniqui and Capas, Tarlac and Balanga and Bagac, Bataan for their cooperation during the survey and collection of test samples; and last but not the least to CIP, Lima, Peru for the NCM-ELISA kit for the detection of 8 sweetpotato viruses.

\section{LITERATURE CITED}

AMANTE, V. DR. and E.T. RASCO, JR., 1995. VSP and its three duplicates. In: E.T. Rasco and V. dR. Amante (eds.) Sweetpotato: Selected papers, July 1993-June 1994. Vol. 2. Southeast Asian Program for Potato Research and Development. Manila. Philippines. pp. 127-131

CAREY, E.E., R. W. GIBSON, S. FUENTES, M. MACHMUD, R. O. M. MWANGA, G. TURYAMUREEBA, L. ZHANG, D. M.ABO EL-ABBAS, F. R. EL-BEDEWWY, and L. F. SALAZAR. 1999. The Causes and Control of Virus diseases of Sweetpotato in Developing Countries: Sweetpotato Virus Disease the Main Problem. In: Impact of the Changing World - Program Report 1997-1998. The International Potato Centre. Lima Peru. 457 pp.

CENTRO INTERNACIONAL DE LAPAPA. 1995. International Potato Centre Program Report 1993-1994. Lima, Peru. 192 pp.

CHUNG, M.L. 1986. Virus Disease of Sweetpotato in Taiwan. In: Plant Virus Diseases of Horticultural Crops in the Tropics ad subtropics. FFTC Book Series 33. Food and Fertilizer Technology Center for the Asian and Pacific Regions, Taipei, Taiwan, ROC. pp. 85-90. 
GIBSON, R.W., G. C. KAITISHA, and J. M. RANDRIANAIVOARIVONY. 1998. Identification of the East African strain of sweetpotato chlorotic stunt virus as a major component of sweetpotato virus disease in southern Africa. Plant Dis. 132:1063.

GUTIERREZ, D., S. FUENTES, J. MOLINA, and L. SALAZAR. 1999. Sweetpotato virus disease (SPVD) in Peru. Fitopatologia 34: 175.

HOYER,U., E. MAISS, W. JEKMANN, D. E. LESSEMANN, and H. J. VETTEN. 1996. Identification of coat protein gene of sweetpotato sunken vein closterovirus isolate from Kenya and evidence for serological relationship among geographically diverse closterovirus isolates from sweetpotato. Phytopathology. 47:582-587.

JAYASINGHE, U. and L. B. LARANANG. 1999. Etiology of "camote kulot" disease in Central Luzon. Philippines. UPWARD Fieldnotes. 8(1): 7-9.

PALOMAR, M. K, E. B. BARSALOTE, and H. S. V. COLIS. 2000. Distribution, transmission and disease characterization of sweetpotato feathery mottle virus. Annals of Tropical Research, 22(1\&2): 16-30.

SALAZAR, L. and S. FUENTES. 2000. Current knowledge on major virus diseses of sweetpotatoes. In: International Workshop on Sweetpotato Cultivar Decline Study. September 8-9, 2000. Kyushu, National Agricultural Experiment Station, Miyakonojo, Japan. pp. 14-19.

SCHAEFERS, G.A. and E. R. TERRY. 1976. Insect transmissions of sweetpotato disease agents in Nigeria. Phytopath. 66: 642-645.

VILLEGAS, L.C., G. L. PAAMULAKLAKIN, E. E. BEDUYA, and M. B. BAJET. 1996. Sweetpotato feathery mottle virus: Its association with "kamote kulot" and its effect on sweetpotato yield. Philippine Phytopathologist, 32(1):35-40.

WINTERS, S., A. PURAC, F. LEGGETT, E.A. FRISON, H. W. ROSSEL, and R. I. HAMILTON. 1992. Partial characterization and molecular cloning of a closterovirus from sweetpotato infected with sweetpotato virus disease complex from Nigeria. Phytopathology, 82:869-875. 